\title{
Cultural learning and historical memory: A research agenda
}

\author{
Aprendizaje cultural y memoria histórica: \\ Una agenda de investigación
}

\section{L'apprentissage culturel et la mémoire historique : Un programme de recherche}

\section{Kevin Myers}

University of Birmingham, UK

\section{lan Grosvenor}

University of Birmingham, UK

\section{ABSTRACT}

Over the past two decades, there have been significant developments in the field of cultural learning. In museums, galleries, archives, and in myriad informal educational activities, children and adults have been encouraged to identify, explore, and celebrate their heritages in an attempt to combat social exclusion and promote individual and collective well-being. This paper argues that projects for cultural learning are important educational interventions, but their operation and outcomes are matters that require further research. In particular, cultural learning offers opportunities for historians of education to critically engage with important topics around history, memory, and identity. Yet, this critical engagement will also require reconsidering and refining the theoretical models currently popular in the history of education.

Key words: cultural learning, memory, identity, social change.

\section{RESUMEN}

Durante las dos últimas décadas ha habido desarrollos significativos en el campo del aprendizaje cultural. En museos, galerías, archivos y en multitud de actividades educativas informales, tanto niños como adultos han sido alentados a identificar, explorar y festejar su patrimonio en un intento por combatir la exclusión social y promover el bienestar individual y colectivo. Este artículo discute si los proyectos para el aprendizaje cultural son importantes intervenciones 
educativas o, por el contrario, su funcionamiento y resultados son asuntos que demandan una atenta investigación. En concreto, el aprendizaje cultural ofrece oportunidades para historiadores de la educación para la participación crítica a partir de temas importantes sobre historia, memoria e identidad. A pesar de que el compromiso crítico requiere reconsiderar y clarificar los modelos teóricos que en la actualidad son populares en la historia de la educación.

Descriptores: aprendizaje cultural, memoria, identidad, cambio social.

\section{RÉSUMÉ}

Au cours des deux dernières décennies, il y a eu d'importants développements dans le domaine de l'apprentissage culturel. Dans les musées, les musées d'arts, les archives et dans une multitude d'activités éducatives non-officielles, les enfants et les adultes ont été encouragés à identifier, explorer, et célébrer leurs héritages dans le but de combattre l'exclusion sociale et de promouvoir le bien-être individuel et collectif. Cet article soutient que les projets d'apprentissage culturel sont d'importantes interventions éducatives mais que leur fonctionnement et leurs résultats sont matière à plus de recherche. En particulier, l'apprentissage culturel offre des occasions pour les historiens de l'éducation de prendre part avec discernement à des thèmes importants concernant l'histoire, la mémoire et l'identité. Néanmoins, cet engagement critique exigera aussi de reconsidérer et de raffiner les modèles théoriques présentement en vogue dans l'histoire de l'éducation.

Mots clés: I'apprentissage culturel, la mémoire, l'identité, le changement social.

\section{Introduction}

$\mathrm{T}$ HE PRINCIPAL THEME OF THIS PAPER IS THE RELATIONSHIP between past and present that may be encouraged by contemporary projects for cultural learning. In museums, galleries, archives, and in myriad informal educational activities, children and adults are encouraged to identify, explore, and celebrate diverse heritages in creative ways. These heritages may be exhibited in museums and art galleries, performed in studios and theatres, explored in archives, collated in oral history projects, or excavated in fields and parks. If it is easy to identify a wide range of cultural learning activities, their operation and their significance are matters that require further research. In particular, exactly how a renewed emphasis on cultural learning influences historical memory, and how it may affect the cognitive architecture of memory, its temporal orientations, and its consequences for subjectivity, are vitally important but open questions. This paper attempts to explain their importance, to sketch a philosophy and method of study, and to elucidate a potential research agenda for historians of education.

In its current manifestations, cultural learning is partly a response to perceptions of epochal change and, in particular, to the challenges allegedly posed by increasingly mobile and diverse populations, sections of whom are understood to suffer from 'social exclusion.' For politicians, policymakers, and educationalists, learning about cultural and community heritage is often heralded as a means of promoting individual well-being and social cohesion. Learning about cultural heritage, it is frequently claimed, promotes self-esteem, good mental health, and community solidarity because it effectively socializes people into values and dispositions that are the result 
of shared historical experiences and which, in turn, promote a sense of belonging (McQueen-Thomson, James, \& Ziguras, 2004; Phinney, Horenczyk, Liebkind, \& Vedder, 2001; Waterton, 2010)

However, and as researchers have frequently noted, these outcomes have usually been claimed rather than demonstrated (Belfiore, 2004; Hewison, 2004; Waterton, 2010). Part of the reason for this is that cultural learning speaks to an ambitious agenda that, as Ken Jones' recent literature review made clear, simultaneously points in two directions: “outwards' to language, rituals, discourses, ideologies, myths and all kinds of systems of signification"; and "inwards' to states of subjectivity that these practices embody" (Johnson, 1986, cited in Jones, 2009, p. 7). In other words, cultural learning pertains to processes of meaning making and to the manner in which individuals and groups use available resources for the purposes of establishing identity and social being (Jones, 2009, p. 8). Historians of education, familiar with practices of learning and socialization, and accustomed to identifying and interpreting social continuity and social change, have a potential contribution to make to developing a research agenda for the analysis of cultural learning as it has developed over the past three decades. Yet, if they are to do so, they may need to depart their familiar spatial, temporal, and intellectual settings. This is because contemporary cultural learning is not confined to state school systems, and it is not concerned exclusively with the past. It is in the dispersed sites of informal education - in museums, community centres, and cafes, in political groups and campaigns, at work and in places of religious worship - that people gather and bring with them versions of the past open for confirmation, reflection, and rejection (Finkelstein, 2013; Macnab, Clay, \& Grosvenor, 2011). This is, to use Catherine Hall's suggestive phrase, to register an interest in the ways in which "history is lived" and, it is argued, historians of education will need to reconsider philosophical and methodological approaches if they wish to embrace new research agendas in this field (Hall, 1996, p. 66).

The paper is divided into three sections. The first section briefly sets out the claims made by some social theorists that the late twentieth century witnessed the emergence of a new historical epoch variously called late modernity, high modernity, or the risk society. Although these claims are often exaggerated, they have been influential amongst social science scholars and, more importantly, their effect has been to promote the idea that there has been a decisive change in the historical consciousness of peoples around the globe. In order to engage with these claims, and to evaluate contemporary cultural education through a temporal lens, historians of education require theoretical models that are robust enough to understand and examine the distinctive features of both social structures and human agency. The second section sets out such a model, taken from the work of critical realists, which allows space for the exploration of both the internal cognitive processes of human beings, and their practical action in the real world. This model is briefly contrasted with popular paradigms in cultural history, the history of education, and history didactics, which have developed in a period of rapid social change and, in their elevation either of discursive structures or inevitable mental processes, have resulted in the diminution of reflective human beings, with "cares, commitments and concerns" (Archer, 2000, 
p. 2), who constitute themselves "out of the historical heritage they make their own, and who transform themselves in terms of the material provided to them from this heritage" (Fay, 1987, p. 164). The third section sets out a potential research agenda for historians of education interested in the ways in which history and memory is utilized for the purposes of identification and social belonging.

\section{Social and cultural histories}

Arguably the most significant historiographical development of the last three decades has been the rise of the 'new cultural history.' Although it shared no cohesive set of topics or themes, the new cultural history, like its predecessor social history, was initially interested in discovering and representing those ignored by dominant historical narratives. Histories of women and children, of ethnic and sexual minorities, of the sick and disabled, expanded the historian's legitimate research agenda and resulted in some groundbreaking publications (Eley, 2005; Fass, 2003). An ethos of 'democratic inclusiveness,' of recognizing the 'people's history and culture,' was an important influence on much of the early work in this tradition (Eley, 2005, p. 10). Inclusive and representative histories were often seen as a tool for promoting democratic and egalitarian political agendas. If history no longer guaranteed the forward march of labour, as the first generation of post-1945 social historians had wished it, it continued to be a source of inspiration and empathy. From it historians and activists could garner esteem, recognition, and security for the proliferating social identities available in societies across the globe (Cook, Glickman, \& O’Malley, 2008).

The belief in the democratizing potential of historical narratives had tangled relationships with the global politics of the 1980s. The final dissolution of European empires, the spectacular collapse of Soviet socialism, and the demise of military dictatorships in Latin America all had the effect of promoting interest in the stories and the cultures hidden by repressive regimes. This was the period of ambitious research agendas into the cultures and experiences of national and imperial 'others'; into First Nation, black, tribal, and ethnic histories (Myers \& Grosvenor, 2011).

The discovery of the hidden histories of the people were simultaneously promoted and challenged by the more intangible, but no less profound, processes of globalization. In particular, the arrival of global economic markets - and the revolutions in travel, communications, and consumption that underpinned them - encouraged a widespread feeling of living through new and uncertain times that was documented by sociologists and commentators around the globe (see, for example, Beck, 1992; Giddens, 1991; Nelson, 2010; Yan, 2010). In one of the most influential of these arguments, Ulrich Beck's Risk Society (1992) declared a break with modernity, a transformation of the foundations of change, and an end to the experience of historical continuity (Beck, 1992; Giddens, 1991). According to Beck, the order and predictability imposed by the institutions of modernism, by the nation state, the nuclear family, local communities, and the hierarchies of class, gender, and race that operated in them, are shaken to their foundations by the aggressive expansion of corporate capitalism that imposes both new opportunities and new risks on individuals. The result of "taking leave of the past," and of abandoning the "traditional way of doing 
things" is, argues Anthony Giddens, a widespread feeling of "ontological insecurity" and an incessant search for meaningful self-identity (Giddens, 1991, p. 55). Or, in the influential argument of French historian François Hartog, because late modern historical consciousness was presentist it was also characteristically anxious and defined by a search for roots, memory, and identity (Hartog, 2003, 2005).

Some circumspection is appropriate when considering these claims. The destruction of tradition and the birth of new kinds of societies were, of course, the central concerns of Marx, Weber, and Durkheim. A melancholy sense of dislocation, and of nostalgia for old traditions and solidarities, is certainly not difficult to identify in the history of sociology. Anxieties around the losses imposed in periods of rapid social change have been a characteristic feature of social science analysis for at least two centuries (Wagner, 2008). Yet, and even if the empirical evidence for the declaration of 'new times' is not always convincing, a common response to feelings of insecurity has been a turn to the past (Myers, 2012). History, and its complex relationships to memory, has been seen as a potential source of security and solidity for individuals, groups, and states.

In the academy, there has been widespread and sometimes vociferous debate, both about this turn to the past and its consequences for modern subjects. Indeed, a defining characteristic of the 'new cultural history' was a radical reappraisal of the methods, theories, and goals of historical study. One powerful line of thinking concerned an alleged decline in historical consciousness, a deep skepticism about the role of historical thinking in any politics of liberation, and a corresponding attempt to examine the ways in which both education, and the specific discipline of history, were enmeshed in discourses that conditioned both subjectivities and processes of identification (Eley, 2005). In their programmatic edited collection, Cultural History and Education, Popkewitz, Pereyra, and Franklin challenged conventional historical practice ('the chronological structuring of events and actions to 'tell' the stories of the past and present") and instead sought to interrogate how "systems of knowledge organise our being in the world, through the construction of rules of reason, the ordering of the objects of reflection and the principles of action and participation" (Popkewitz, Pereyra, \& Franklin, 2001, p. x). "History," they declared, "is the critical engagement of the present by making the production of collective memories available for scrutiny and revision," but in the most abstract, and strongly constructionist versions of these arguments, it was sometimes hard to identify who was capable of undertaking the project of critique or what its outcomes might be (p. 4). This was partly because agents of history were downgraded from sovereign individuals to an "effect of power," and partly because any political claims were limited to "problematising the subject" (p. 175).

In fact, and as the critique of radical romanticism advanced in new cultural histories of education, the question of human agency in history became increasingly contested. Foucault's enormous influence, and his stress on the discursive formation of human subjectivity, stimulated increasing scrutiny of knowledge practices and their impact on identities. This was evident in studies of formal education that deployed a language of governmentality, and of experts, institutions, discourses, and disciplines 
that explained new forms of modern subjectivity (See, for example, Franklin, 1999; Peim, 2001; Popkewitz, 2013; Verstraete, 2007). The empirical results of this agenda have been considerable, not least in opening up critical conversations about the fundamental aims, theories, and methods of historical research - but this is an opportune moment to repeat two key reservations, and to add a third, in respect of the new cultural histories of education (Grosvenor \& Myers, 2006). Firstly, Foucault was certainly an imaginative and inventive historian but, as the late Raphael Samuel argued in a sympathetic account of his work, he used historical materials in "unfamiliar and deeply mysterious ways" and was quite "indifferent to the weight of the past, or indeed the actual course of events" (Samuel, 1992, p. 234). Secondly, Foucault's work was associated with the tendency to treat knowledge as a function of power and to abandon any serious attempt at the sociology of knowledge (Sayer, 2000, chapter 2). This helps explain the anti-humanist tone of the strongly constructionist writings in the new cultural history of schooling. Thirdly, and whilst a scholarly concern with identity is one of the ubiquitous results of the 'cultural turn,' historical studies still regularly imply and suggest, rather than explain and delineate, models of identity (Brubaker \& Cooper, 2001; Fields, 2001). The result has been significant confusion around theories of identity; a related tendency to conflate personal and social identities; and a dominating interest in the production, surveillance, and regulation of both bodies and emotions in educational history (for some examples, see Burke, 2007; Donald, 1992; Gleason, 1999). The terms agency, actors, and resistance often appear in these studies, but they are usually as a kind of afterthought, whose basis is rarely clear and whose import tends to be minimal.

Now, whilst there are very good reasons not to picture the human actor the "a priori of historical studies" (Popkewitz, 2013, p. 4), and to endorse attempts by the new cultural history to move beyond rational actor models, there are also good reasons to insist on the different ontological properties of the social and the individual (or of structures and agents, or parts and people) that exist independently - and inescapably - through time. Human beings are embodied and bodies have properties and powers of their own. Arguably the most important such property, and certainly the most relevant here, is the "power to know ourselves to be the same being over time" (Archer, 2000, p. 7). The emergence of selfhood, of a continuous sense of self and self-consciousness, is dependent on memories that are not only declarative (consciously recalled facts or information) but also procedural (skills learnt through repetition in the engagement with the natural order) and eidetic (the detailed and affective recognition, rather than the recall, of visual images). Being Human, to adopt the title of Margaret Archer's important work, is to experience a continuous sense of being that emerges from engagement with the world. This engagement stimulates procedural and eidetic memories that provide the basis of selfhood, which are, importantly, both non-linguistic and posterior to both personal and social identities. It is through embodied practical relations that selfhood, reflexivity, memory, and thought develop, and from which both personal and social identities will emerge (Archer, 2000, pp.137-145).

This model of human agency is, in our view, consistent not only with the new 
cultural history but also with historical sociology and historically informed social science (Steinmetz, 1998). It allows for the ways in which history is lived by individuals situated in real historical time, who are capable of locating themselves in sociohistorical processes and reflecting on and reworking constructions of that process (Myers, 2011, 2012, 2015; Trouillot, 1995). This may have become a more pressing necessity for successive generations of people living through periods of rapid social change. The slow and painful decline of industrialism, a transformation in urban landscapes, a shift in the type and patterns of work, and an associated decline in the strength and consciousness of the manual working class entailed, according to the risk sociologists, a shift in social and political imaginaries. Nations and classes, the staple categories of identification of the twentieth century, lost their dominance. The identities of individuals and groups were increasingly understood not as a final product but an on-going project, and one dependent on the autobiographical constructions of individuals who, divorced from the traditions and structures that once defined them, were forced to continually reflect on, and fashion, themselves in relation to society. These were the newly reflexive individuals proclaimed by social theorists (Fanshawe \& Sriskandarajah, 2010)

All this had important consequences for the meanings attached to the past. No longer necessarily anchored to nations and classes, the manner in which individuals processed and stored information and, in particular, exactly how memory was related to identity, became a major area of scholarly enquiry. Across the arts and humanities, the social sciences, and in health sciences, too, scholars became interested in the ways in which history, as narrative and/or memory, framed processes of subjectivity and identification; how it linked or bridged agents to social structures; and about the ways in which the availability and deployment of historical narratives conditioned the politics of recognition (Radstone \& Schwarz, 2010, pp. 1-9; Winter, 2012;).

\section{Memory, identity, and the cultural meaning of the past}

Historians may have been reluctant to enter detailed discussions around cognitive processes, but they could detect distinctive orientations towards, and uses of, the past. Carolyn Steedman, for example, argued that in the late twentieth century individuals inhabited and used the past more affectively. The past, she wrote, was "a place of succour and strength, a kind of home," and in "the project of finding an identity through the process of historical identification, the past is searched for something (someone, some group, some series of events) that confirms the searcher in his or her sense of self, confirms them in what they want to be and feel in some measure that they already are" (Steedman, 2001, pp. 76-77). For historian Peter Mandler, the opportunity to fix one's individual identity was one of the "new social purposes of history" (Mandler, 2002, p. 148). For individuals and groups who faced what appeared like new times, previously authoritative and natural versions of the past appeared suddenly fictive and fragile (Anderson, 1983; Hobsbawm \& Ranger, 1983). Marx and Engels may have predicted how "all that is solid melts into air"' under the conditions of capitalist modernity, but it would take a further century for the prescience of the observation to become evident (Hobsbawm, 2011, pp. 110-113). Looking back 
on the period 1945-1990, the late Eric Hobsbawm concluded it was the "the greatest and most dramatic, rapid and universal social transformation in human history" (1994, p. 288).

In an era of rapid social change, marked not least by the emergence of a truly global economy, by decolonization and international migration, and by revolutions in technology, transport, and social attitudes, older imperial and national master narratives began to break down. Established cultural practices and idioms, enforced by the conventionalism of relatively stable societies, gave way to a much proclaimed sense of discontinuity. If this sense of new times was shared by millions, it is perhaps in the biographies of migrant women - playing a very significant part in the slow demise of global peasantry, in the doubling of the world rate of urbanization between 1950 and 2010, the rapid expansion of secondary and higher education, and in the reconstitution of labour markets and personal relationships - that it was most clearly exemplified (Therborn, 2011, p. 170). Unprepared by their pasts for their futures, women were prominent amongst the reflective minds who had to "grope for words to name the unknown” (Hobsbawm, 1994, pp. 287-288; Moya \& McKeown, 2010; Smith, 2010).

This, rather sweeping, sketch necessarily minimizes important geographical differences and there remained, of course, very different life course experiences for rich and poor, especially for those amongst the latter located in the pastoral societies of sub-Saharan Africa. Nonetheless, no area of the world was unaffected by rapid social change and, perhaps just as importantly, no region went untouched by the advances in communications technology. The proliferation of printed texts, radios and televisions, the emergence of mobile telephones, and the internet not only provided new sources of information and enabled the construction of new communities, they may have done so in qualitatively new forms. Historian Bill Schwarz argues, for example, that the invention of electronic media not only meant that the "means by which people learnt to understand themselves as historical individuals changed profoundly," they introduced a specifically mediated form of knowledge with their own narratives and sensations of time (Schwarz, 2004; 2011, p. 197; Hoskins, 2004). It has become a commonplace claim that the invention and rapid distribution of electronic and social media constitutes a further revolution in communications technology, but scholars are only just beginning to seriously consider how these changes can be conceptualized so that their consequences, both for the structure of knowledge and processes of identification, can be adequately evaluated (see, for example, Goodman \& Parisi, 2010; Schwarz, 2014; Soar, 2011). What can be said with some certainty is that individuals and groups have actively negotiated these resources and out of them developed new forms of social difference (Myers, 2015; Wetherell \& Mohanty, 2010). These include the construction and distribution of ethnic or cultural identities fed by a powerful sense of being forgotten or excluded from a wider national narrative or identity. Moreover, and in Western Europe at least, if this was historically a claim reserved for black immigrants, it has recently been voiced for a white working class whose resentments have stimulated a resurgence in virulent nationalism (Ford \& Goodwin, 2014). Amongst the many explanations for this phenomena, Jerome 
de Groot's suggestion that the proliferation of histories in the media "leads to the excessive protecting of certain tribal or ethnic histories" certainly deserves greater attention (2006, p. 411).

Yet, and irrespective of causes and even taking into account different chronologies and circumstances in different regions, individuals and groups did become increasingly detached from national myths of manifest destiny, and from simple linear narratives of national progress and development. If this was the consequence of global structural change, it was one that was widely welcomed and encouraged. For a rather eclectic collection of mainstream politicians, revolutionaries and radicals, scholar activists, academics, social psychologists, and educationalists, the national master narratives of colonial nations were identified as a source of enduring psychic damage. Indigenous and colonized peoples, it was frequently argued, had suffered not only from political domination but a more insidious exclusion from the systems of thought that ruled the world. The "scientific discipline of history" was identified as culpable and European historiography exposed for its part in creating the cultural conditions, and intellectual arguments, for colonialism and imperialism (Majumdar, 2010; Myers, 2015).

This was, or came to be known, not without controversy, as the postcolonial (or post-colonial) moment. For radicals and revolutionaries committed to the Third World project, the contrasting works of Fanon and Friere were sources of inspiration. In the academy, various strands of feminist theory, and of tools and concepts from cultural and literary studies, were used to explore what Foucault called the power/ knowledge nexus in the establishment of "regimes of truth." For educationalists in Europe beginning to recognize the effects of domestic racism, it was the tradition of research represented by Kenneth and Mamie Clark, so influential in the 1954 landmark case of Brown vs. Board of Education of Topeka, that provided a conceptual model that was fleshed out and developed in social identity theory and loosely applied in schemes of multicultural education (Patterson, 2001; Myers, 2015). Yet, what united these diverse currents was a commitment to new forms of historical memory.

In the more applied elements of this work, historical memory was conceptualized as both affective and therapeutic. Social psychologists argued, for example, that historical narratives could help stimulate the emotions that underpinned self-esteem, secure identity, and tolerance for others. In one of the most influential educational studies in post-1945 England, David Milner's Children and Race (1975) interpreted the apparent preference of black children for white identities as a form of self-rejection conditioned by racism and by the negative connotations attributed to black skin. Similar arguments were made for other minority groups, especially the largest immigrant population in Britain, the Irish. Addressing colleagues, for example, Liam Greenslade (1996) advised: "Our task as social psychologists must entail the longrange strategy of re-connecting us as communities to our historical experience, to give us back not merely our voice but our memory of who we are and what we might become" (p. 125).

The potential of history, or perhaps more accurately, memory, to stabilize identities and stimulate particular forms of action or behaviour made it attractive to 
governments and policymakers. In some countries - most notably the USA, the UK, and Australia - and an increasing number of international organizations and agencies, questions around history and memory were part of a wider focus on the psychological and emotional states associated with 'social exclusion' (Estivill, 2003). In the UK, the influential Social Exclusion Unit, a social policy think tank located in the Cabinet Office between 1997 and 2010, identified historical narratives and memories as critical resources for establishing and maintaining community identities. Arts education, and cultural activities more broadly, were valued because they helped "communities to express their identity, develop their own, self-reliant organisations" that related "directly to individual and community identity" (Policy Action Team 10, 1999, p. 8). "Recognising and developing the culture of marginalised people and groups," it was argued, "directly tackles their sense of being written out of the script" (p. 30). In what some critics saw as a new therapeutic ethos in governance, subordinated histories could be incorporated into official narratives in an attempt to promote individual well-being, social belonging, and to recast local, regional, and national identities as modern, progressive, and cosmopolitan (Ecclestone \& Hayes, 2009; Furedi, 2004; Wright 2011).

These projects helped to stimulate considerable controversy and global contests over the politics of knowledge, the so-called wars over history and culture, and demonstrated disparate views on the relationships between past, present, and future (Macintyre \& Clark, 2003; McCormack, 2007; Phillips, 1998). In an often rancorous politics of memory, cultural restorationists and social conservatives insisted on the values, obligations, and identities imposed by customs and traditions that came from the past. The metaphors employed by Ronald Reagan's speechwriters - of history as a "ribbon," a "connecting thread," or "a river whose long, winding course bound together the generations of the past" - imagined the legacies of the past to be self-evident; a common national culture, established moral codes, patriotism, and a secure national identity (cited in Rodgers, 2011, pp. 221-225). All were said to be under attack from liberal or progressive insurgents who, it was claimed, sought to destabilize gender roles, usurp established religions, and denigrate great civilizations. Although these culture wars had specific national and regional inflections, they were typically found in ferocious educational debates around the history curriculum, the national canon, and the teaching and practice of religion (see, for example, Symcox, 2002).

The control and management of schools have, of course, long been issues of political and cultural conflict. This is because they continue to be treated by politicians, commentators, and academics as critical sites of knowledge production and social reproduction. Indeed, it is almost an axiom of public debate that schools retain the power to teach or deliver identities. Arguably the closest that sociologists have come to justifying this truism is in the profoundly influential work of Pierre Bourdieu, for whom it was a foundational premise that "there exists a correspondence between social structures and mental structures" that is reproduced "semi-consciously and quasiautomatically” (Bourdieu, 1977, p. 477). Yet, this concept (or, for some, method) of habitus, that allegedly operated "beyond the grasp of consciousness" (Bourdieu, 
1977, p. 94), was both vague and so loosely applied that it led sociologist Diana Reay to complain that "a great deal of educational research references habitus instead of working with the concept as Bourdieu advocates. Habitus is assumed or appropriated rather than 'put into practice' in research accounts, and it appears that it is 'the gravitas of habitus' that is desired rather than its operationalization" (Reay, 2004, p. 440). Even when appropriate care is exercised, however, there are reasons to doubt whether Bourdieu's habitus, or other varieties of correspondence theory, are sufficiently robust to capture the ways in which individuals use memories for the construction of identity. This is because data from the social sciences consistently indicates the complexities of identity formation, and insists on the centrality of a thinking and reflective subject (Fanshawe \& Sriskandarajah, 2010; Wetherell \& Mohanty, 2010).

In particular, and despite the tendency for simplification in popular accounts of neuroscience, the most convincing accounts of the role of memory in the formulation of identity postulate a movement through individual childhood memories (in which the visual or eidetic is particularly prominent, resilient, and the source of a continuous sense of self) and towards collective memories that reside in cultural artefacts, and perhaps especially, in texts, tapes, discs, and computers - but which also must be accessed, experienced, ordered, and assessed before the meanings and ideas within them are taken up or rejected. In short, human memory is an active process that requires perceptual filtering, selection, reflection, and recall that is sensitive to time, place, and purpose (see, for example, Rose, 1992; Sutton, Harris \& Barnier, 2010).

However, even in otherwise important and interesting work on cultural learning, historians and educationalists continue to be hampered by restrictive conceptual frameworks (Macnab, Clay, \& Grosvenor, 2011). One recent example, based on an impressive corpus of some four thousand student narratives of Québec history collected by historian Jocelyn Létourneau, found that "students' usable past is very much shaped by forces outside the realm of formal education" (Lévesque, Létourneau, \& Gani, 2013). The everyday historical memories carried, as it were, by students in their heads, mirrored or echoed a wider public culture where the survival of Québec, and its people, is a theme repeated by the media, political leaders, and pop artists. This is a valuable corrective to routine claims that young people in modern societies did not know or care about history, and a clear indication of the limitations of school history curricula as a practical tool in the construction of social identity. As Létourneau and others have demonstrated, other historical memories - mined from a wide variety of personal, familial, and communal resources - form the basis of social identities that are characterized by ambivalence, fluidity, and complexity (Fanshawe \& Sriskandarajah, 2010).

Yet, the processes through which historical resources are selected and employed by individuals remain elusive. This is hardly surprising. Identities, mentalities, and memories are crucial questions for both historians and social scientists, but they are not easily resolved. Nonetheless, whilst Létourneau's work points in the right empirical direction, it is also reductive for both methodological and conceptual reasons. Methodologically, students were expressly invited to recount only the history 
of Québec, pointing them unambiguously towards the national and ethnic identities that frame the research and so also delimiting their recourse to other possible histories, memories, and narratives. Conceptually, the empirical data is explained by reference to the Social Identity Theory (SIT) pioneered by Henri Tajfel, who influentially argued that the complexity of modern societies required individuals to develop mental schemata that classified and categorized external information. In doing so, individuals were able to make sense of the world around them. A particular interest for SIT, evident in the work of educators in multicultural settings, has been around how the construct of ethnicity is used by individuals to identify and establish in-group and out-group preferences (see Phinney, 1990). The narratives offered by Québec students may have been "naive" and "simplified" write Lévesque, Létourneau, and Gani (2013), but "the way young French Québécois frame their stories serve an extremely useful purpose for them; they help position their ingroup (French Canadians) in opposition to a dominant, imperialist outgroup, les Anglais. By doing so, students develop a predictable pattern of meaning-making which simplifies past realities into a dichotomous story of 'us versus them'” (p. 165). This may be accurate, but it is also a predictable finding from a research project that probed popular understandings of the past, elides important distinctions between personal and social identities, and was framed by a theory that regards categorization and stereotyping as a fundamental, and perhaps even permanent, part of ordinary cognition. Students in Québec might easily access a popular and simplified ethnic narrative of the past, but this hardly exhausts the abilities of a thinking and reflective subject.

Indeed, part of the problem with SIT is that, in a period of rapid social change, of migration, border crossings, and flux and fluidity, it remains reliant on rather static in-group and out-group distinctions. The diverse processes invoked by the term 'globalization,' and especially the proliferation of available social identities in modern societies, mean that research that prioritizes particular constructs, and especially accounts of race and ethnic identity, are prone to simplification. The current educational interest in intersectionality is one response to this position. Yet there remains much to do before a convincing account of the relationship between historical memory and both personal and social identity is established. Any such account has to wrestle with far-reaching economic, social, and technological changes that have rendered individuals increasingly responsible for their life paths, susceptible to growing inequalities in material resources, life chances, and access to information and which may have made historical memories at once more important, more elusive, and more fluid. Tracing their construction and application in diverse sites of cultural learning presents considerable research challenges.

\section{Cultural learning: A research agenda}

When a selection of experienced historians in the United States of America were asked to identify future research agendas, Barbara Finkelstein responded by writing of her inclination to spend less time on systems and structures and more about education history "in relation to movement and place, the lived experience of migration, dislocation, border crossings, cultural encounters, inter-dependence, the forming of 
social identities, and senses of belonging" (2013, p. 126) This is an ambitious agenda worth endorsing, and a modest start may be to begin research with contemporary people, who carry some of that history in their biographies, and into the spaces of informal education concerned with both the past and the present.

Informal cultural learning is certainly becoming recognised as an important area for theoretical and applied research. To take one pertinent example, the European Union's Horizon 2020 Research and Innovation program challenges scholars to contribute to "the building of inclusive, innovative and reflective societies." Its vision, supported by significant funding, is to produce a Europe comprised of reflective societies, able to critically explore its "historical, cultural and normative roots"; willing to promote affective forms of belonging for its diverse citizens; and whose creativity, resilience, and tolerance will produce a Europe united by its diversity (European Commission, 2013, p. 32) A consistent feature of the more specific topics promoted in the research program is a concern with how processes of remembering and forgetting help to "inform and reorganise the terrain of politics itself" (Radstone \& Schwarz, 2010, p. 2). Historical memory, "the uses of the past," and cultural heritage, values, and language are, it is claimed, "crucial for the collective memories and sociability of groups but also for the personal development of citizens, enabling them to find their place in society" (European Commission, 2013, p. 34). Yet, and whilst this kind of assertion is commonplace in policy documentation, relatively little is known about how these processes operate in practice. Whilst recognizing that there are potentially many routes for further research, four might be considered particularly appropriate and important for historians of education.

Firstly, and because contemporary cultural learning projects are located in the informal education sector, and because they often have limited funding and fixed timescales attached to them, not enough is known about their number or their activities and how these vary at the national, regional, and local levels. It is reasonable to suppose that, alongside the rapid expansion of the heritage sector over the last two decades, projects for cultural learning have proliferated. There is a need, therefore, for descriptive data that provides some indication of geographical variations in the practice of cultural learning. It should be noted in passing that even this relatively simple enumeration of activity will require a shared and consistent typology of cultural learning activities that enable comparative study.

Secondly, projects for cultural learning have become commonplace as societies across the globe have sought to respond to social change. Yet, the particular social changes that are identified as requiring intervention, and who defines them, are matters for empirical examination. The specification of social problems entails, after all, an exercise of power which focuses attention on particular actors, processes, and periods. An important aim here is to consider the complexities involved in the narration of social change. Whilst structural transformations have affected the material conditions of life for all areas of the globe, how change is perceived and understood varies in different cultural locations and is conditioned by the assignment of individuals to different positions in society. Put bluntly for reasons of brevity, it is important to know which interest groups come to define dominant chronologies of social change, 
how they do so, and whose accounts are silenced or marginalized as a result.

It is worth stressing that this analysis is not limited to the professional historiography of nation states. Indeed, it is arguably a key element in the research agenda proposed here that relationships between past and present, and between memory and identity, became increasingly contested towards the end of the twentieth century. This was not only attributable to regime change, and the decline of authoritarian states, in various parts of the world. It was also related to the democratization of the means of cultural production, the emergence of new technologies, and, perhaps more geographically specifically, the expansion of higher education which helped produce, in turn, a post-1968 generation of activists committed to social change and with access to new languages of social analysis. There is a need to understand how those languages conceptualized relationships between memory and identity, and how these may have informed educational and political practices (see, for example, Grosvenor, 2012; Grosvenor \& Hall, 2012; Myers, 2015). Prosography is one potential method for tracking the activities and influences of social activists in different geographical locations.

Thirdly, the deployment of those languages of social analysis varied across the globe, but one arguably consistent feature was the claim that there were missing or marginalized stories to be told, or taught or popularized. Projects for cultural learning typically sought to tell these stories. In doing so, they routinely produced new artefacts designed to inform and educate the public, or a portion of it, about these subaltern pasts. Indeed, it is not difficult to identify a proliferating material culture of the past that emerged from cultural learning projects. Even a selective list of these products might include historical murals, local history pamphlets, oral histories (and their transcripts), exhibition displays, scripts for dramatic performances, songs and music, and, finally, digital representations and accounts of the past (Grosvenor, 2008, pp. 212-214). So the third element in the proposed research agenda would be to attempt to itemize these kinds of products, to track their movement and their consumption. A working hypothesis here is that different types of products, or different genres of historical representation, have specific codes whose access and intelligibility varies. Complex academic works of sociology or history may be materially and conceptually inaccessible to all but the educational elite, for example, but images have historical associations that may be at once more accessible and more promiscuous. The point to stress here is the proliferation in the historical materials available to subsequent generations and with which social identities might be formed.

Finally, and perhaps most challengingly, because the research would be concerned with the take up and transformation of heritage, it would be necessary to conduct field research into the ways in which individuals and groups construct meaning from the material culture of the past. It follows from the conceptual framework outlined earlier in the paper that this would entail the actual analysis of cultural learning projects in practice. Thus, and although attempts at the transmission of historical memories are certainly important, this research agenda is just as concerned with the ways in which historical subjects construct past-present relationships and make them meaningful. Historical subjects are located in time and assigned different positions 
in society according to class, gender, and ethnicity. Our working hypothesis is that, being differentially conditioned, actors deploy distinctive tools to access and interpret materials relating to the past. Again, whilst there is insufficient space to flesh out a methodology in detail, the research would be interested in ascertaining the extent to which people have become progressively divorced from national master narratives that served to socialize groups into national narratives, values, and identities. If there has been an increase in the diversity of history 'as it is lived,' then it should be possible to track, through pedagogical activities and interviewing, how and what people remember and how their experiences - immediate, concrete, and digital - enable and constrain their historical imaginations.

\section{References}

Anderson, B. (1991). Imagined communities: Reflections on the origin and spread of nationalism (revised ed.). London, England: Verso.

Archer, M. (2000). Being human: The problem of agency. Cambridge, England: Cambridge University Press. http://dx.doi.org/10.1017/CBO9780511488733

Belfiore, E. (2002). Art as a means of alleviating social exclusion: Does it really work? A critique of instrumental cultural policies and social impact studies in the UK. International Journal of Cultural Policy, 8(1), 91-106. http://dx.doi. org/10.1080/102866302900324658

Bourdieu, P. (1977). Outline of a theory of practice (R. Nice, Trans.). Cambridge, England: Cambridge University Press. http://dx.doi.org/10.1017/CBO9780511812507

Brubaker, R., \& Cooper, F. (2000). Beyond 'identity.' Theory and Society, 29, 1-47. http:// dx.doi.org/10.1023/A:1007068714468

Cook, J. W., Glickman, L., \& O’Malley, M. (Eds.). The cultural turn in US history: Past, present and future. Chicago, IL: University of Chicago Press.

Curthoys, A. (2003). Constructing national histories. In B. Attwood \& S. G. Foster (Eds.), Frontier conflict: The Australian experience (pp. 185-200). Canberra, Australia: National Museum of Australia.

Donald, J. (1992). Sentimental education: School, popular culture and the regulation of liberty. London, England: Verso.

Eley, G. (2005). A crooked line: From cultural history to the history of society. Ann Arbor, MI: University of Michigan Press.

Ecclestone, K., \& Hayes, D. (2009). The dangerous rise of therapeutic education. London, England: Routledge.

Estivill, J. (2003). Concepts and strategies for combating social exclusion: An overview. Geneva, Switzerland: International Labour Office.

European Commission: Horizon 2020. (2013). Europe in a changing world - inclusive, innovative and reflective societies. http://ec.europa.eu/research/participants/data/ref/h2020/ wp/2014_2015/main/h2020-wp1415-societies_en.pdf

Fanshawe, S., \& Sriskandarajah, D. (2010) 'You can't put me in a box': Super-diversity and the end 
of identity politics in Britain. London, England: Institute of Public Policy Research.

Fass, P. (2003). Cultural history/social history: A continuing dialogue. Journal of Social History, 37(1), 39-46.

Fay, B. (1987). Critical social science: Liberation and its limits. Ithaca, NY: Cornell University Press.

Fields, B. J. (2001). Whiteness, racism and identity. International Labor and Working Class History, 60, 48-56

Finkelstein, B. (2013). Teaching outside the lines: Education history for a world in motion. History of Education Quarterly, 53(2), 126-138. http://dx.doi.org/10.1111/hoeq.12011

Flusche, D. M., \& Korth, E. H. (1983) Forgotten females: Women of African and Indian descent in colonial Chile 1535-1800. Detroit, MI: Blame Ethridge.

Franklin, B. (1999), Review essay: The state of curriculum history. History of Education, 29(4), 459-76. http://dx.doi.org/10.1080/004676099284573

Ford, R., \& Goodwin, M. (2014). Revolt on the right: Explaining support for the radical right in Britain. London, England: Routledge.

Furedi, F. (2004) Therapy culture: Cultivating vulnerability in an uncertain age. London, England: Routledge.

Goodman, S., \& Parisi, L. (2010). Machines of memory. In S. Radstone \& B. Schwarz (Eds.), Memory: Histories, theories, debates (pp. 343-363). New York, NY: Fordham Press.

de Groot, J. (2006). Empathy and enfranchisement: Popular histories. Rethinking

History: The Journal of Theory and Practice, 10(3), 391-413. http://dx.doi. org/10.1080/13642520600816171

Giddens, A. (1991). Modernity and self-identity: Self and society in the late modern age. Cambridge, England: Polity.

Gleason, M. (1999). Normalizing the ideal: Psychology, schooling and the family in postwar Canada. Toronto, Canada: University of Toronto Press.

Greenslade, L. (1996). V.N. Volosinov and social psychology. In I. Parker \& R. Spears (Eds.), Psychology and society: Radical theory and practice. London, England: Pluto.

Grosvenor, I., \& Hall, A. (2012). Back to school from a holiday in the slums! Images, words and inequalities. Critical Social Policy, 32(1), 11-30. http://dx.doi. org/10.1177/0261018311425197

Grosvenor, I. (1999). 'There's no place like home': Education and the making of national identity, History of Education, 28(3), 235-250. http://dx.doi. org/10.1080/004676099284609

Grosvenor, I. (2008). From the 'eye of history' to a 'second gaze': The visual archive and the marginalised in the history of education. In J. Goodman, G. McCulloch, \& W. Richardson (Eds.), Social change in the bistory of British education (pp. 205-220). London, England: Routledge.

Grosvenor, I. (2012). 'It is on the site of loss that hopes are born.' Migration, education and the writing of history. In E. Declercq, W. Kusters, \& S. Vanden Borre (Eds.), Migration, intercultural identities and border regions (19th and 20th centuries, pp. 29-48). Brussels, Belgium: Peter Lang.

Hall, C. (1996). Histories, empires and the post-colonial moment. In I. Chambers \& L. Curtis (Eds.), The post-colonial question: Commons skies, divided horizons (pp. 65-77). New 
York, NY: Routledge.

Hartog, F. (2003). Régimes d'bistoricité. Presentisme et expériences du temps. Paris, France: Seuil.

Hartog, F. (2005). Time and heritage. Museum International, 57(227), 7-18. http://dx.doi. org/10.1111/j.1468-0033.2005.00525.x

Hewison, R., \& Holden, J. (2004). Challenge and change: HLF and cultural value. London, England: Demos.

Hobsbawm, E., \& Ranger, T. (Eds.). (1983). The invention of tradition. Cambridge, England: Cambridge University Press.

Hobsbawm, E. (2011). How to change the world: Tales of Marx and Marxism. London, England: Little Brown.

Hobsbawm, E. (1994). Age of extremes: The short twentieth century, 1914-1991. London, England: Penguin.

Hoskins, A. (2004). Television and the collapse of memory. Time and Society, 13(1), 109-127. http://dx.doi.org/10.1177/0961463X04040749

Hunt, L. (1989). Introduction. In L. Hunt (Ed.), The new cultural history. Berkley and Los Angeles, CA: University of California Press. http://dx.doi.org/10.1525/ california/9780520064287.003.0001

Jones, K. (2009). Culture and creative learning: A literature review. Newcastle, England: Creativity, Culture and Education.

Lévesque, S., Létourneau, J., \& Gani, R. (2013). 'A giant with clay feet': Québec students and their historical consciousness of the nation. International Journal of Historical Learning, Teaching and Research, 11(2), 159-175.

McQueen-Thomson, D., James, P., \& Ziguras, C. (2004). Promoting mental health and well being through community and cultural development. Melbourne, Australia: Globalism Institute.

Myers, K., \& Grosvenor, I. (2011). Birmingham stories: Local histories of migration and settlement and the practice of history. Midland History, 36(2), 140-162. http://dx.doi.org /10.1179/004772911X13074595848915

Myers, K. (2011). 'Faith in history: Memory, multiculturalism and the legacies of Empire in post war England. History of Education, 40(6), 779-793. http://dx.doi.org/10.1080/0046 760X.2011.620014

Myers, K. (2012). Marking time: Some methodological and historical perspectives on the 'crisis of childhood.' Research Papers in Education, 27(4), 409-422. http://dx.doi.org/10.10 80/02671522.2012.690237

Myers, K. (forthcoming, 2015). Struggles for a past: Irish and Afro-Caribbean histories in England, 1951-2000. Manchester, England: Manchester University Press.

Nelson, M. K. (2010). Parenting out of control: Anxious parents in uncertain times. New York, NY: New York University Press.

Patterson, J. A. (2001). Brown v. Board of Education: A civil rights milestone and its troubled legacy. Oxford, England: Oxford University Press.

Peim, N. (2001). The history of the present: towards a contemporary phenomenology of the school. History of Education, 30(2): 177-190. http://dx.doi. org/10.1080/00467600010012454

Phillips, R. (1998). History teaching, nationhood and the state: A study in educational politics. London, England: Routledge. 
Phinney, J. S., Horenczyk, G., Liebkind, K., \& Vedder, P. (2001). Ethnic identity, immigration and well being: An interactional perspective. Journal of Social Issues, 57(3), 493-510. http://dx.doi.org/10.1111/0022-4537.00225

Pickering, M., \& Keightley, E. (2006). The modalities of nostalgia. Current Sociology, 54(6), 919-941. http://dx.doi.org/10.1177/0011392106068458

Popkewitz, T. (2013). Styles of reason: Historicism, historicizing and the history of education. In T. Popkewitz (Ed.), Rethinking the history of education: Transnational perspectives on its questions, methods and knowledge (pp. 1-28). New York, NY: Palgrave Macmillan. http:// dx.doi.org/10.1057/9781137000705

Radstone, S., \& Schwarz, B. (Eds.). (2010). Memory: Histories, theories, debates. New York, NY: Fordham University Press.

Reay, D. (2004). 'It's all becoming a habitus': Beyond the habitual use of habitus in educational research. British Journal of Sociology of Education, 25(4), 431-444. http://dx.doi. org/10.1080/0142569042000236934

Rodgers, D. T. (2012). Age of fracture. London, England: Harvard University Press.

Rose, S. (1992). The making of memory. London, England: Bantam Press.

Sayer, Andew. (2000). Realism and social science. London, England: Sage. http://dx.doi. org/10.4135/9781446218730

Smith, B. (2010). Women in the twentieth century world. In M. Adas (Ed.), Essays on twentieth century history (pp. 83-115). Philadelphia, PA: Temple University Press.

Soar, D. (2011). 'It knows.' London Review of Books, 33(19), 3-6.

Steinmetz, G. (1998). Critical realism and historical sociology: A review article. Comparative Studies in Society and History, 40(1), 170-186. http://dx.doi.org/10.1017/ S0010417598980069

Steedman, C. (2001). Dust. Manchester, England: Manchester University Press.

Stern, S. J. (1992). History, historiography and politics. Journal of Latin American Studies Supplement, 24, 1-34. http://dx.doi.org/10.1017/S0022216X00023750

Sutton, J., Harris, C. B., \& Barnier, A. J. (2010). Memory and cognition. In S. Radstone \& B. Schwarz (Eds.), Memory: Histories, theories, debates. New York, NY: Fordham University Press.

Symcox, L. (2002). Whose history: The struggle for national standards in American classrooms. New York, NY: Teachers College Press.

Therborn, G. (2011). The world: A beginner's guide. Cambridge, England: Polity Press.

Trouillot, M. R. (1995). Silencing the past: Power and the production of history. Boston, MA, Beacon.

Verstraete, P. (2007). Towards a disabled past: Some preliminary thoughts about the history of disability, governmentality and experience. Educational Philosophy and Theory, 39(1):

56-63. http://dx.doi.org/10.1111/j.1469-5812.2007.00239.x

Wagner, P. (2001). A history and theory of the social sciences. London, England: Sage.

Waterton, E. (2010). Politics, policy and the discourses of heritage in Britain. Basingstoke, England: Palgrave Macmillan. http://dx.doi.org/10.1057/9780230292383

Wetherell, M., \& Mohanty, C. (Eds). (2010). Sage Handbook of Identities. London, England: Sage. http://dx.doi.org/10.4135/9781446200889.n1

Winter, A. (2012). Memory: Fragments of a modern history. Chicago, IL: University of Chicago 
Press.

Wright, K. (2011). The rise of the therapentic society: Psychological knowledge and the contradictions of cultural change. Washington, DC: New Academia.

Yan, Y. (2009). The individualization of Chinese society. Oxford, England: Berg. 
